\title{
Analysis of aesthetic
} minimalism: a look at of the

\section{creative process in minimalists Brands Design}

Análise do minimalismo estético: um olhar acerca

do processo criativo no Design de Marcas minimalistas

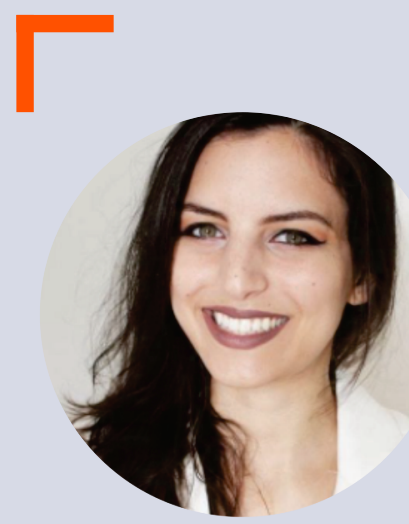

\section{Nárima Alemsan}

PHD student in the Postgraduate Program in Engineering and Knowledge Management EGC at the Federal University of Santa Catarina - UFSC, she has a master's degree in the Postgraduate Program at EGC Engineering and Knowledge Management - UFSC and have a degree in Graphic Design at the University of the State of Santa Catarina - UDESC narimalemsan@gmail.com

\section{Francisco Antônio Pereira Fialho}

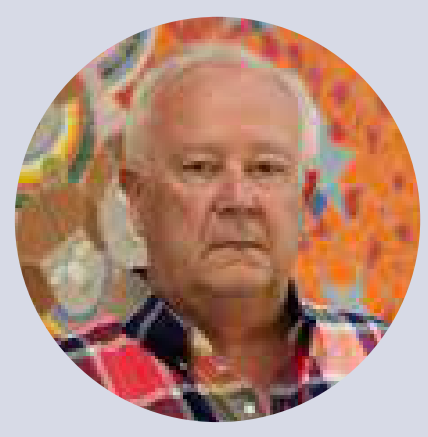

PhD professor in the Postgraduate Program at EGC Engineering and Knowledge Management at UFSC. Master's Degree in Production Engineering, Ergonomics, from the Federal University of Santa Catarina (1992) and Ph.D. in Production Engineering, Knowledge Engineering, from the Federal University of Santa Catarina. fapfialho@gmail.com 


\section{ABSTRACT}

The search for a more sustainable and at the same time clean and elegant style is increasingly present in people's lives in order to have greater sustainability, freedom from excess for the awareness of what really matters which reflects in the aesthetic standards in the area of Design . The creative process starts to reflect also through society's behaviors. In this case, more specifically in the construction of Brand Design. So, aesthetic minimalism is also increasingly present in brand design projects, reflecting consumer behavior. This article aims to address the definitions of aesthetic minimalism present in brand design projects in their creative process. To understand all these aspects, a theoretical foundation, relevant discussions and analysis of the creative process of a minimalist brand were made. The methodology used for this article was qualitative exploratory research. Finally, final considerations are presented, addressing the impact and importance that these changes can have within design styles in the creative process for professionals in the field.

\section{KEYWORDS}

Minimalism; Brand design; Creative process.

\section{RESUMO}

A busca por um estilo mais sustentável e ao mesmo tempo clean e elegante está cada vez mais presente na vida das pessoas a fim de se ter maior sustentabilidade, libertação de excessos para a consciência do que realmente importa o qual reflete nos padrões estéticos na área do Design. O processo criativo passa a refletir também através de comportamentos da sociedade. Neste caso, mais especificamente na construção de Design de marcas. Então, o minimalismo estético se faz cada vez mais presente também em projetos de Design de marcas em reflexo ao comportamento dos consumidores. Este artigo tem como objetivo geral abordar as definições do minimalismo estético presente em projetos de design de marcas em seu processo criativo. Para compreender todos esses aspectos, foi feita uma fundamentação teórica, discussões pertinentes e 


\section{RESUMO}

análise das etapas do processo criativo de uma marca minimalista. A metodologia utilizada para o presente artigo foi a pesquisa exploratória qualitativa. Por fim, é apresentado as considerações finais abordando o impacto e importância que essas mudanças podem ter dentro dos estilos de design no processo criativo para profissionais da área.

\section{PALAVRAS-CHAVE}

Minimalismo; Design de marcas; Processo criativo. 


\section{INTRODUCTION}

In recent years there has been a change in people's behavior as a result of the exaggerated consumption proposed by the Media. People began to question themselves and review why so much consumption. "The idea revolves around voluntary simplicity, which starts with the reduction of consumption and reaches all spheres of life: work, food, relationships, health" (ROJAS; MOCARZEL, 2015).

Thus, a new lifestyle emerged: minimalist. However, different from what many people think about the minimalist lifestyle, this one isn't just about reducing the consumption of a product or wearing clothes with straighter shapes and few colors, but it is about how to live with the environment in a conscious way. and significant. It can be said that in this sense there is a concern for the environment and sustainability. It's about releasing excesses in multiple aspects to focus on what really matters. This worldview turns to the essence or the essential. In order to fully understand this context, a historical review from the 1980's onwards is brought forward.

Minimalism expanded into design in the 1980's, after Functionalism in the 1960's and the subjectivist trend in the 1970s. Subjectivism in design was part of the postmodernist movement, in which artists drew objects of different formats and languages, with variations of colors and other characteristics that were the opposite of what was applied in the functionalist movement.

In Functionalism, the only objective of the object was its functionality, a characteristic similar to the original minimalist style of the sculptures, consisting of lines and right angles, use of geometric shapes and without color variations.

The minimalist style is taking large proportions around the world. With each passing day, it is more common to come across logos, visual identities or graphic productions that have lighter lines and basic geometric shapes.

The methodology used for this article was qualitative exploratory research in which "...as a research exercise, it does not present itself as a rigidly structured proposal, it allows the imagination and creativity to lead researchers to propose works that explore new approaches ". (GODOY, 1995, p.23). Therefore, approaching subjective aspects of social phenomena and human behavior. 
From the literature review studied, the term aesthetic minimalism was not found in the main stages of the creative process applied specifically to brand design projects.

\section{DEVELOPMENT}

\subsection{Aesthetics of Minimalism}

Minimalism had its relevance in the 60's as it opposed the current movements of the time (CERVO, 2005). Minimalism is the elimination of the unnecessary and the preservation only of the essentials. It has been present in the arts and culture media since the 1960s, but it had signs much earlier, cited, for example, in the phrase "Simplicity is the maximum sophistication - Leonardo Da Vinci" (BARBOSA, 2017, p.21). Since then, this aspect has expanded to various areas of society.

The expression minimalism comes from the English "minimal art" and refers to the movements born in New York in the 1950s/1960s. In the field of arts, it is basically characterized by few elements, colors and the use of simpler forms without so many details, that is, with little visual information, but which still has a lot of meaning.

It starts, therefore, from the much talked about assumption that less is more. Less: consumption, less exaggerated elements and more elegance in form, more space and more aesthetically acceptable to the behavior standards of today's society. It is in the work that "beauty is manifested more by subtraction than by addition, in a very rigorous process that eliminates everything that is not essential" (ZABALBEASCOA; MARCOS, 2001, p. 65, apud SCHMIDT, 2014, p. 6).

\footnotetext{
Minimalism preserves a reduced and at the same time enlarged version of modernity: the lack of ornament - a rigorous and intensified application -, the use of simple geometric volumes - reduced to straight geometries -, preferentially straight angles and a supposed universality of language.
}

From this conception, the term essential enters with much more importance in the construction aspects of a minimalist brand design. For Rojas and Mocarzel, (2015) Minimalism, as an expression of essence, reminds us of the transcendence of art as a sense of the sensitive and as a communication full of meanings and associations. Aesthetic minimalism is configured in a more essential set "like geometric shapes, flat surfaces and 
neutral color, simplicity and literality" (MANUEL, 2007, p.2).

Graphic design is an area so favorable to minimalism that it gave space and opportunity for the emergence of a new trend based on this style, Flat Design. "Also known as Flat Design, it is a visual trend applied to layouts and digital interfaces. Its greatest feature is the elimination of any detail that is not strictly necessary, such as shadows and textures." (NASCIMENTO, 2018, p.14).

Thus, minimalism is a style with visual simplicity in a more elegant, light and current way and is reflected in brand design projects. To understand all this, it is first necessary to correlate with the terms: language, culture and aesthetic manifestation.

\section{LANGUAGE AND AESTHETIC MANIFESTA-}

\section{TION}

The language itself is the way people establish their relationship with the world and as everything. This can happen in various aspects of expressions, such as: verbal or non-verbal, among so many other expressions. One of the oldest languages is the visual language. Lupton and Miller, regarding theorizations that treat abstract forms as ownership of their own language reinforce that:

The term visual language is a common metaphor in the modern design manuals: a 'vocabulary' of design elements (dots, lines, shapes, textures, colors) is organized by a contrast 'grammar' (instability / swing, asymmetry symmetry, soft / rigid, heavy light). (LUPTON; MILLER, 1999, p. 64)

And from these languages, many movements have emerged in society in order to framed each style at a given time. In postmodern society experiences a more focused design in experience and ends up becoming more minimalist.

Minimalism doesn't react, therefore, against the middle, but against mediation, invoking an end of figurability or at least an inviveration of the traditional figures of nature and man. To this crisis of mediation delayed through the crisis of the appearance and realization of the permanent has to correspond to the minimalism the reduction of representative content, that is, to reduce the way visible to its simplest expression. Going out of the letter and the importance of communication remains discreet behind the creation process. (ROJAS; MOCARZEL, 2015, p.132) 
According to the authors mentioned, reducing representative content for the simplest expression is one of the paths of the creative process of this style. It is not easy to remove many details of a design or symbol that is already in our memories. But design professionals can train this observation about minimalism in their projects.

According to Caution and Zurlo, the creative process frame consists of three elements (2006, p. 43-44):

1) the design, understood as the process that, guided to change the dimensions, characteristics, and expressive forms of existing situations, uses the visualization as an instrument to negotiate, direct and take choices, decisions and solutions.

2) The company, and especially the company of high involvement with design, that is, a company in which design is not employed only in the development of new products, but which relates it comprehensively to the dynamics and business processes. A company in which project activities for the development of new products are integrated into the daily life of business management;

3) the strategy, which we can consider as the preferred field of relationship of the relationship, consistent in determining objectives and milestones of the business life cycle and in the continuous activity of reception, interpretation and appropriation of stimuli and impulses, endogenous or exogenous, perhaps only perceptible.

To better understand this creative process within minimalist design is shown below an outline of the great artist Pablo Picasso, for example, was a revolutionary artist in this sense, in which he designed the minimalist "essence" of the animal shape with fluid lines as shown in Figure 1:

Figure 1 - Croqui "Bull".

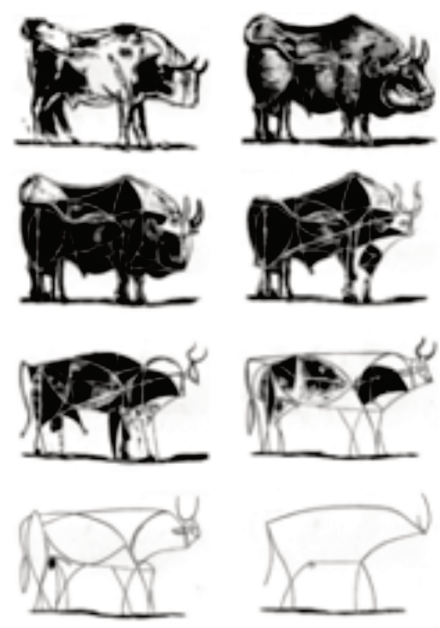

Source: (PICASSO, Pablo, 1945 apud LUCIA, Carmen, 2016) 
It can be realized that in Figure 1 it has a decrease in animal details and fills, remaining the main lines or only the initial geometry. Aesthetic minimalism, therefore, is a movement that has emerged through behavioral changes over a few years which have reflected in the daily behavior of people and also within the design field choices more specifically in brand design. Which can be called minimalist design of brands with less traces, more elegance, spatiality and visually more current and modern.

With these new dimensions, projects come to have a simpler look, but it doesn't stop carrying the meanings present in the symbols. Then the butterfly symbol can be used with fewer strokes and fills and still maintains the transformation meaning for example. In this way, aesthetic minimalism has been making a lot of space in brand design projects.

\subsection{Design styles}

There are several styles present in brand design or logo design construction. Today's society receives a diversity of styles that contribute to the construction of projects with more purpose and more meaning in people's lives.

The purpose-based differentiation process takes place through the way people think and act, with the different styles being influenced by the symbols that make up each style that make up the design. Thus, knowing design styles is a way of understanding the genesis of each code created from a socially and culturally marked reality.

According to the authors Linke; Calvi; Do Bem (2020) emphasize that "Style is a way of expressing the identity of people/artists, objects/product, architecture, etc."

\subsection{Marks and brand design}

In the context of Brand Design, it is important to understand the constituent elements. One of them is the brand and is widely used in organizations and is represented by artistic letters or types, as the name says, containing the full name of the brand. Another fundamental element for brand design is typography, although it is often seen as just words, it can convey a message through text and its style and becomes quite functional in this use. The typographies, for example, can be with serifs and handwritten. 
The symbol was signed with initial letters and is often used when it is not legible, for example, in posting images and videos on Instagram or Facebook.

\subsection{Color and language}

According to Ambrose and Harris (2005), color is one of the most important elements in the field of Design. Color has the ability to awaken people's emotions loaded with meaning, "color is, in fact, impregnated with information. It is, therefore, an invaluable source for visual communicators" (DONDIS, 2003, p. 64).

The psychological character of color, its ability to awaken different emotions, must be considered. Each color takes on unique combinations. These can arouse desire in people and provoke different sensations in people.

Then, through color, try to work on emotion, which is not at the level of imagination, as the visual sensation is unique and real. From the moment that symbolic values are assigned to colors, they begin to represent various symbolic elements. "Every color also has certain cultural connotations" (FISCHER-MIRKIN, 2001, p. 28). In the process of building brand design, the choice of colors or, more commonly, the use of the color palette is considered.

\subsection{Creative process in brand design}

For Brand Design to be established it is necessary to go through the creative process of the Design professional. Creativity in design is defined by Raquel Rohenkohl (apud Luiz Gomes Filho $(2001$, p.9) as "[...] the set of factors and processes, attitudes and behaviors that are present in the development of productive thinking".

Thus, "Creativity has always been a word intrinsically associated with design. This becomes more evident when, turning our gaze to the past, we pay attention to the fact that the English word design is associated, in its Latin origin, with desígnio, intention, purpose, whose meanings accompany, in our cultural tradition, the different meanings of creation." (SILVA, 2013 p. 2)

Thus, the creative process depends on a few steps. Some of these are: briefing, tests, adjustments, and final project. In general: "The creative process is never fully formatted inside the mind because it consists in 
doing. Furthermore, there are always deviations, mistakes, improvisations and surprises that help to produce a work." (LOYAL, 2019)

Adiloglu (2011) states that effective visual information resides in creativity, in addition to belonging to an interdisciplinary field. Therefore, visual tools are strong allies for the development of innovation. Thus, Creativity is understood as "thinking the new and acting on the new" (Flemming and Mello, 2003, p. 9).

Baxter (2000, p. 51) defines that "[...] creativity is the heart of design, in all stages of the project." Creativity in design can be defined, according to Gomes (2001, p. 9), "[...] as the set of factors and processes, attitudes and behaviors that are present in the development of productive thinking". There are some steps to achieve greater creative capacity in Design. The three main steps pointed out by Buzan (2005) are:

a) Seeing things from different points of view - People in general see things from a single point of view, usually their own. The creative designer sees things from an infinite number of angles and perspectives. This skill is also essential to think about all the necessary possibilities about the product in relation to direct and indirect users, as well as the manufacturing system, the availability of the product on the market, etc.

b) Establishing creative relationships - New things relationships, in ways that were previously unheard of, provide originality to the project. The ability to relate is extremely important in design, adding aspects to objects, such as multifunctionality and interactivity.

c) Invert things - The inversion skill comes from the opposite interpretation of things. With the inversion it is possible to find results for unusual and unusual projects.

To understand the theory presented, we provide an example of branding for a customer served online in Sao Paulo city. The color designed for the new premium brand was an older shade of pink, referring to aspects of care, well-being, and coziness.

The symbol designed was the union of the heart with the shape of a leaf, it was used precisely to recall the feeling of taking care of food and the love for a healthier lifestyle. It reinforces the care with this new lifestyle as shown in figure 2: 
Figure 2 - Premium brand design

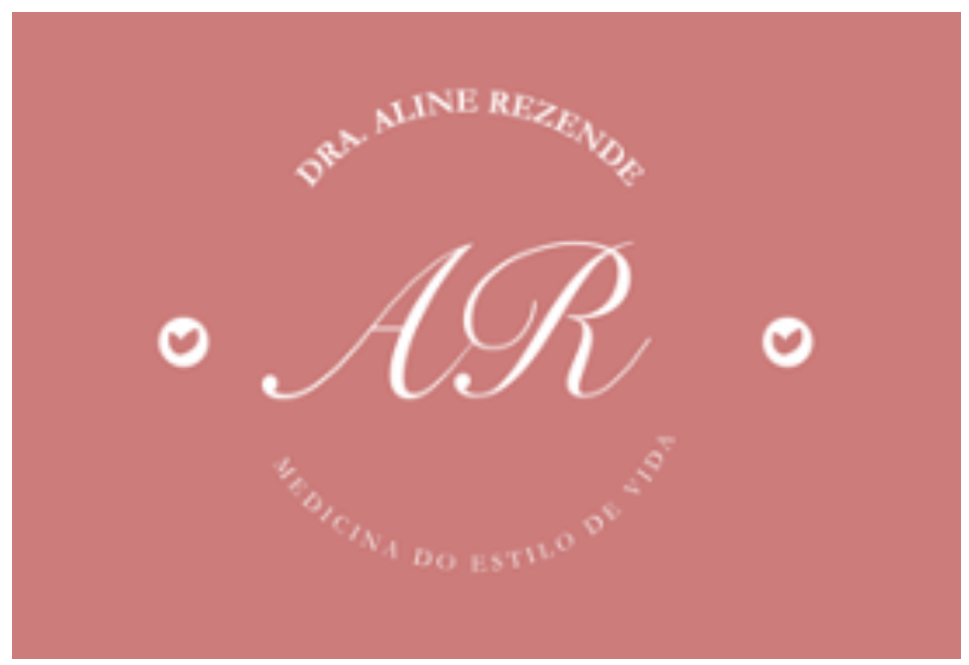

Source: (ALEMSAN, Nárima, 2021)

We perceive, therefore, a lightness in the traces, but at the same time with few elements that refer to health, lightness and life quality which were identified in the project briefing. The brand essence remains even with few elements and traces.

The rebranding can range from a small logo evolution toward a total change in the color, style and appearance of the brand. It all depends mainly on what message it wants to convey from this remodeling, which is the main factor of a visual identity. (DO BIRTH, 2018, p. 17)

Removing heavier fills and shapes, exaggerated gradients, and also removing many layers of the symbol design and typography, we arrive at a lighter form of the brand. Coming, thus, to the minimalist brand design. As shown in figure 2. In short, the 7 main steps identified in the creative process for Brand Design with aesthetic minimalism were:

1) Define the meaning for the symbol,

2) Adjust the lines more evenly,

3) Remove excess fillers and gradients,

4) Use few colors,

5) Align the brand elements,

6) Remove exaggerated outlines,

7) Maintain the harmony of the elements (typography, symbols, colors, and tagline).

Putting all these elements together, the creative process for minimalist design becomes easier to apply. If less is more, then symbol excesses and multiple details used in Brand Design are eliminated. Thus, with these 
eliminations, the concept in Brand Design remains and at the same time it becomes simpler, not losing its initial concept thought of in the first stage of creation.

\section{FINAL CONSIDERATIONS}

According to the literature review, no studies were found on how the creative process takes place through stages in the new aesthetic minimalism style applied to Brand Design, which may, therefore, be a new style to be deeply studied and applied to Brand projects.

This article contributes to the advancement of knowledge for professionals in the field of Design, identifying important elements in Brand Design and bringing a new perspective of minimalist style to the creative process.

Thus, the term aesthetic minimalism in the creative process becomes an important style within the field of Design and influences choices in the process of creating a new brand. There are many definitions about the theme, but in general the Minimalist Brand Design is the construction of the symbol loaded with meaning with a minimalist style without many details and fillings reflecting a social movement present in today's society.

So, going back to the paradigm "less is more" one has that less information and details keeping the essence of meaning in minimalist brands design. The analyzed studies made it possible to investigate the creative process of design and the influence of minimalism in people's lives mirroring in brand design projects. A strong expansion of this style will provide a greater connection with the public with increasing digital access.

So, the minimalist style is beyond visual simplicity and at the same time it is loaded with meaning through symbols presented in a more elegant, light, modern and at the same time very current. The seven (7) main steps were identified in the creative process for Brand Design with aesthetic minimalism.

Many contributions emerge regarding this study: a new style to be thought by Design professionals. Observation of brand details ends up being greater. Increase expectations about the digital market. Information presented on different platforms needs to be clearer for the people aligning thus to this most current minimalist style.

Thus, the minimalist brand design is, therefore, a style to be studied by professionals in the field with greater visual simplicity in a more elegant, light and, at the same time, modern way, reflecting the consumption of a 
movement of contemporary behavior.

\section{REFERENCES}

ADILOGLU, Fatos. Visual communication: design studio education through working the process. Procedia-Social and Behavioral Sciences, v. 28, p. 982-991, 2011.

A LEMSAN, Nárima. Figure 2: Available at: https://www.mentoriadigital7.com.br/portfolio Access in: May 2021.

BAXTER, Mike. Product Design: Practical guide for the design of new products. 2. Ed. rev. São Paulo: Edgard Blücher, 2000.

BUZAN, Tony. The power of creative intelligence: 10 ways to activate your creative genius. São Paulo: Cultrix, 2005.

ESTEVÃO, Vanessa Sofia Paulino. The trend towards minimalist design. 2015. Doctoral thesis.

OF CASTRO, Eduardo B. Nurseries. Minimalist society: on the subject of a book by Peter Rivière. Anthropological directory, v. 10, n. 1, p. 265-282, 1986.

FLEMMING, Diva Marília; Mello's collation, Ana Claudia. Creativity and didactic games. Saint Joseph: Saint-Germain, 2003.

GODOY, Arilda Schmidt. Qualitative research: fundamental types. Business Administration Magazine, v. 35, n. 3, p. 20-29, 1995.

GOMES, Luiz Vidal Negreiros. Creativity: Design - Design - Product. Santa Maria: Schds, 2001.

MANUEL, Victor. Minimalism and post minimalism: form, anti-shape and body in the work of Robert Morris. Covilhã: Books Labcom, 2007.

NASCIMENTO, Sara Mendes do. Minimalism in design MIV design for icy magic. 2018.

LEAL, Pandemonium: Creative process, experimentation and chance. 2019. Doctoral thesis. University of Sao Paulo.

LINKE, Paula Piva; CALVI, Gabriel; DO GOOD, Natani Aparecida. Visual language: design and style. Projética, v. 11, no. 1 supp. 32-56.

LUCIA, Carmen. Figure 1: BULL, Available at: $<$ http://oquevidomundo.com/foco-nas-artes-guernica-picasso/> Accessed in: May 2021.

LUPTON, Ellen; MILLER, Abbott. Design Writing Research. 1st ed. London: Phaidon, 1999.

MARTINS, Heloísa Helena T. Qualitative research methodology. Education and research, v. 30, n. 2, p. 289-300, 2004. 
PICASSO, Pablo. [Bull]. 1945. Sketch painted in graphite.

ROHENKOHL, Rachel. Creativity and Design: an analysis of the creative ability in the design process. Available at: file: $<$ https://portalperiodicos.unoesc.edu.br/acsa/article/view/1484/pdf $>$. Accessed on: May 30th of 2021.

ROJAS, Angelina Accetta; MOCARZEL, Marcelo Maia Vinagre. From visual culture to material culture: minimalism as a form of expression in consumer society. Alceu Magazine, v. 16, no. 31, p. 131-140, 2015.

SCHMIDT, Laila Rotter. Less is More: Intersections Between the Emergence of Modern Graphic Design and Mies Van Der Rohe's $\mathrm{M} \mathrm{i} \mathrm{n}$ i m a I i s m. A $v$ a i I a b I e a t : $<$ https://www.proceedings.blucher.com.br/article-details/less-is-moreintersees-entre-o-surgimento-do-design-grfico-moderno-e-ominimalismo-de-mies-van-der-rohe-12697> Accessed on: 15 May. 2021.

SILVA, Sérgio Antônio; DA SILVA, Sérgio Luciano. The Aristotelian concept of Mimesis applied to the creative process in design. Design Studies, v. 21, no. 1, 2013.

SZABAT, Carla Natacha; MESACASA, Andréia; WAGNER, Priscilla Gil. MINIMALISM. In: 8thJEPEX and 2nd Mostra. 2019.

TORRES-ANGENOT, Hecate et al. The use of visual tools to aid the design creation process. 2020.

ZURLO, Francesco. New Entertainment and Design Strategico. 2006. 


\section{Nárima Alemsan}

PHD student in the Postgraduate Program in Engineering and Knowledge Management (EGC), she has a full Master degree in Engineering and Knowledge Management (in the Media area). Graduation in Graphic Design from UDESC. It integrates the groups: the Center for Studies and Developments in Knowledge and Consciousness - NEDEC and the Research Center for Complexity and Cognition-NUCOG. Area: Arts, Design. Interdisciplinary topics of interest: creativity, humanities, management, branding, Arts, new media, culture, philosophy, network society, design thinking, digital transformation, awareness, visual identity, psychology, innovation and communication.

Publications available at:

http://lattes.cnpq.br/5610173778609242

\section{Francisco Antônio Pereira Fialho}

Currently is a full teacher at the Federal University of Santa Catarina UFSC. Graduated in Electronic Engineering from the Pontifical Catholic University of Rio de Janeiro (1973) and in Psychology from the Federal University of Santa Catarina (1999), Master degree in Production Engineering, Ergonomics, from the Federal University of Santa Catarina (1992) and PHD in Engineering of Production, Knowledge Engineering, by the Federal University of Santa Catarina (1994). He has experience in the field of Knowledge Engineering and Management, working mainly on the following topics: knowledge engineering, knowledge media, ecoergonomy, knowledge management and cognitive ergonomics. Leader of the Center for Studies and Developments in Knowledge and Awareness NEDECC. Leader of the Complexity and Cognition Research Center NUCOG.

Publications available at:

http://lattes.cnpq.br/1602495591542111 